\title{
Improving teachers' teaching abilities in the era of the ASEAN Economic Community by the teacher's professional coaching
}

\author{
A. Imron, B.B. Wiyono, I. Gunawan, B.R. Saputra*, D.B. Perdana \& S. Hadi \\ Universitas Negeri Malang, Indonesia
}

A. Abbas

International Islamic University Islamabad, Pakistan

\begin{abstract}
The main concept of ASEAN Economic Community (AEC) is to make ASEAN a single market and production-based unification by 2015. As part of ASEAN, Indonesia has to integrate its economic and human resource capabilities in the AEC. It is necessary to identify the characteristics of the AEC, as well as prepare the students and the teachers to teach people who are ready to face the AEC era. To provide those qualified teachers, continuous professional coaching is necessary to improve their commitments and teaching capabilities. Therefore, research that produces a model of professional teacher coaching that ensures the realization of teachers' instructional skills for the AEC era is required. It is necessary to get guidance from previous studies that have done that in facing global challenges. This professional coaching aims to improve teachers' teaching skills through a variety of supervision techniques.
\end{abstract}

Keywords: Teacher's professional coaching, teacher professionalism, teaching abilities, economics community.

\section{INTRODUCTION}

The leaders of the governments of ASEAN countries in October 2014 created an agreement by signing the ASEAN Concord-2 in Bali. Among these agreements, the ASEAN Economic Community (AEC) was established as the realization of the ultimate goal of economic integration as outlined in the ASEAN Vision 2020, which is to create a stable, prosperous and highly competitive ASEAN economic region (Ministry of Trade 2013). In the ASEAN region, there will be the free trade of goods, services, investments, and capital flows (Mantra 2011). The AEC blueprint had been declared at the 13th ASEAN Summit in Singapore in 2007 (ASEAN Secretariat 2008).

Reviewing the student ability survey released by the Program for International Student Assessment (PISA) in 2019, Indonesia is ranked 72nd out of 77 countries (Viva 2019). On the other side, the news portal Tirto released the Education Index data based on Human Development Reports (2017). According to the data, Indonesia is placed seventh in ASEAN countries with a score of 0.622 . This ranking is still considered lagging behind other ASEAN countries, such as Singapore (0.832), Malaysia (0.719), Brunei Darussalam (0.704), Thailand, and is just ahead of the Philippines (0.661). Ben-Yehuda (2015) stated that the teacher professional coaching program had a significant effect on the students' academic ability. Teacher professional coaching is a crucial aspect that should be developed sustainably. This development can be built through good relationships in training, self-reflection of each individual on their abilities, experiences on challenging new insights and experiments with new ideas (Patti et al. 2012). The optimization in every stage of teacher professional development should be integrated with the support of the school principals and supervisors.

\footnotetext{
*Corresponding author: bagusrachmad47@gmail.com
} 
The substance of the blueprint was the strategic schedule for realizing the 2015 AEC. The professionalism that has been developed this way is expected to impact the teacher's teaching ability in the learning process. According to the research conducted by Sudjana (2002), the professionalism of teachers has quite dominantly influenced the student's learning process by $76 \%$. The teacher's professionalism includes $32.43 \%$ for teaching ability, $32.38 \%$ for mastery of the subject matter, and $8.60 \%$ for teacher's attitudes towards related subjects. Based on the background of the problem and the lines of thought described above, this paper further examines the appropriate teacher professional coaching to improve their teaching abilities in facing the era of the AEC, entitle "Teacher's Professional Development to Improve the Teaching Ability of Teachers in the Era of the AEC."

\section{TEACHER'S PROFESSIONAL COACHING IN THE AEC ERA}

Professional coaching has established ethics, competencies, proficiencies, and masteries that take the process of adult learning far beyond what was possible before with the help of particular supervisors and their advice on how to manage classrooms or teach lessons. The coaching emphasizes that the teacher's professionalism improvement should be the focus of the teacher's professionalism coaching as well as building their commitment through mentorship. Teacher professional coaching also covers training in the adaptation of the profession of teachers and managers in education systems. In addition, the purpose of the teacher's professional coaching is to improve the teacher's commitment with the influence of leadership and working conditions on teacher commitment as well as with the development and maintenance of high levels of commitment among teachers (Imron 2016).

Sobri (2013) explained that professional coaching for teachers is an attempt or activity carried out in a structured manner to obtain optimal results for teachers in self-development and learning. Teacher's professional coaching, according to the Ministry of Education and Culture, is a series of activities that provide assistance to teachers, especially in the form of professional service assistance, which is carried out by school principals, school owners, supervisors, and others to improve the teaching and learning process and outcome.

In creating high-quality lesson planning, the teacher's ability is required in order to design a learning process that refers to qualitative and quantitative improvisations. Usman (2009) describes that ability or competence should be the primary consideration in rationalizing a predetermined goal according to actual conditions. Thus, the teacher's teaching ability is a self-reflection of their capabilities, encouraging students to learn and develop continuously (Sauri 2010). Commitment is an essential element of successful teaching; committed teachers are concerned with their students' development and profoundly struggle with how to keep students learning. Increasing teacher commitment in teaching will have a positive impact on student learning outcomes. The teacher will really focus and pay attention to students, not just doing work but truly committed to helping students find their potential. Teacher commitment has been identified as one of the most critical factors for the future success of education and schools. Teachers committed to the teaching profession are thought to be more satisfied with the job and are likely to identify themselves as teachers. The level of teacher commitment is considered a critical factor in the success of the current educational reform agenda as it heavily influences teachers' willingness to engage in cooperative, reflective and critical practice (Imron 2016).

\section{TEACHING ABILITY IN THE AEC ERA}

AEC is one of the pillars of the long-term plan launched by ASEAN. The purpose of the AEC itself is to manifest an integrated system in the economic field or a single market implemented by the countries in it. The improvements in the teacher's ability have a significant effect on producing better students. The demands for highly competitive professionals in the AEC era are the key 
to be able to compete in the AEC single market flow. In the AEC itself, there are challenges in employment, one of which is to present competitions in terms of education, productivity, skills, and abilities. The teacher's ability will affect the learning outcomes that the students will achieve. The essence of being an effective teacher lies in knowing what to do to foster pupils' learning and being able to do it (Kyriacou 2007). Rubio (2009) divided teachers' teaching abilities into two aspects: personal abilities and professional abilities. The teacher's professional skills are content knowledge, good planning, clear goals and communication, good classroom management and organization, and consistently high and realistic expectations with the students are essential factors to be effective teachers (Rubio 2009). The teacher's personal skills are caring, knowing the students individually, fostering teacher-student relationships, and creating an effective classroom environment (Rubio 2009).

In order to be prepared to manage AEC with its competitive trade traits, services, and professionals, a professional teacher with better abilities is needed. Therefore, teachers' teaching ability needs to be optimized to educate students who are already prepared to approach the AEC era. A high level of teaching ability is necessary, but it is still not sufficient to face the AEC era if it is not being complemented with a high commitment to educating the students. That is why the teacher's commitment and teaching ability are two inseparable sides of the same coin (Imron 2016). Optimization of each side is needed through professional coaching, both by school principals and school supervisors. The knowledge, skills, and commitment of teachers, as well as the quality of school leadership, are the essential factors in achieving high-quality educational outcomes (European Commission 2013).

\section{TEACHER'S PROFESSIONAL COACHING TO OPTIMIZE THE TEACHER'S TEACHING ABILITY IN THE AEC ERA}

In order to provide proper teacher professional coaching, Dreyfus and Rabinow (1986) recommend standing on the teacher's level of development on their teaching maturity and abilities. The first level is the novice level, when the teacher presumes that personal practical experience is more valuable than verbal information. Teachers at this level are taught the meaning of certain terms and concepts, school rules, and the situation's objectives and characteristics. Second, the advanced level starts from influencing their behavior in a meaningful way. At this level, teachers do not feel a sense of independence/autonomy concerning their work. Teachers still feel completely irresponsible for their actions.

The third level is the competent level, or when the teacher has moved and has enough experience and motivation to succeed. Fourth, the proficient level is when the teacher begins to recognize formulas and equations holistically. Fifth, the expert level is when the teacher has demonstrated performance and decision-making intuition. They present it in a distinctive and qualitative way to other teachers. Kasule et al. (2014), in their research, stated that the teacher's professional coaching program should involve five domains/areas of competences that have to be achieved by a teacher that acts as: (1) an innovator; (2) a community science developer; (3) a network maker; (4) an educational designer; and (5) an entrepreneur. Kabilan (2004) shows that there are five aspects of teacher competence that are useful for improving the teacher's competence, namely: (1) motivation; (2) knowledge and skills; (3) independent learning; (4) interaction competencies; and (5) awareness of technology.

Mevarech (1995) describes several steps in the process of teacher's professional coaching, namely: (1) survival; (2) exploration and bridging; (3) adaptation; (4) conceptual changes; (5) discovery; and (6) experiments. Contingency theories recommend a model of teacher's professional coaching based on the level of maturity (LoM), level of responsibility (LoR), and concern of teacher (CoT). Teachers with a mature LoM, independent LoR, and professional CoT are recommended to use a nondirective model. Meanwhile, teachers with immature LoM, dependent LoR, and self-CoT are advised to use the directive model. On the other side, teachers with growing LoM, autonomous LoR, and CoT students are recommended to use the directive model. 


\section{CONCLUSION}

In confronting the era of the ASEAN Economic Community (AEC), improvements in the educational sector are very fundamental. These improvements aim to produce teachers who are qualified to be educators who are competitive with foreign teachers. In addition, teachers with qualified teaching qualities will produce high-achieving and talented students as well. Teacher professional coaching is conducted to support the teachers in improving their teaching abilities and awareness of their responsibilities as educators. Teacher's professional coaching is organized systematically by the principal, school supervisor, or the education office. Some issues that must be considered in conducting teacher's professional coaching programs are the integration of a set of structures, concepts, and competencies in value education that the teachers have to be master. The professional coaching activities that are being carried out should be cooperative, collaborative and constructive based on the teacher's empirical experience in learning. Thus, the deficiencies in learning activities can be evaluated by providing solutions and innovations to creating an optimized learning objective according to the circumstances.

\section{REFERENCES}

ASEAN Secretariat. 2008. ASEAN Economic Community Blueprint. Jakarta: Public Affairs Office, ASEAN Secretariat

Ben-Yehuda, M. 2015. The Route to Success - Personal Academic, Coaching Program. International Conference Education, Reflection, Development (ERD 2015). Social and Behavioral Sciences.

Dreyfus, H, and P Rabinow. 1986. What is Maturity? Foucault and Habermas on What is Enlightenment? In Foucault, M., and Hoy, DC Oxford: Blackwell: Foucault: A Critical Reader.

European Commission. 2013. Supporting Teacher Competence Development: For Better Learning Outcomes. Brussels: European Commission.

Imron, Ali. 2016. Strengthening School Quality Management in the MEA Era. Paper presented in the Seminar on Strengthening Quality Management and Educational Leadership in the MEA Era and Globalization, Postgraduate Program. Malang: State University of Malang.

Kabilan, MK 2004. Online Professional Development: A Literature Analysis of Teacher Competency. Journal of Computing in Teacher Education.

Kasule, GW, R Wesselink, O Noorozi, and M Mulder. 2014. The Current Status of Teaching Staff Innovation Competence in Ugandan Universities: Perceptions of Managers, Teachers, and Students. Journal of Higher Education Policy and Management.

Kyriacou, C. 2007. Essential Teaching Skills. London: Nelson Thornes, Ltd.

Mantra, D. 2011. Hegemony and the Discourse of Neoliberalism: Tracing Indonesia's Steps towards the 2015 ASEAN Economic Community. Jakarta: Mantra Press.

Mevarech, ZR 1995. Teachers Paths on the way to and from the Professional Development Forum. New York: Teachers College Press.

Ministry of Trade. 2013. Towards the 2015 ASEAN Economic Community. Jakarta: Ministry of Trade of the Republic of Indonesia.

Patti, J, AA Holzer, R Stern, and MA Brackett. 2012. Personal, Professional Coaching: Transforming Professional Development for Teachers and Administrative Leaders. Journal of Leadership Education 11(1).

Rubio, CM 2009. Effective Teachers: Professional and Personal Skills. Ensayos, Revista de la Facultad de Educación de Albacete.

Sauri, Sofyan. 2010. Building national character through teacher professionalism development based on value education. Journal of Character Education 2 (2): 1-15.

Sudjana, Nana. 2002. Assessment of Teaching and Learning Process Results. Bandung: Youth Rosdakarya.

Sugiyono. 2016. Metode Penelitian Kuantitatif Kualitataif dan Kombinasi (Mixed Methods). Journal of Chemical Information and Modeling.

Sobri, Ahmad Yusuf. 2013. Fostering Teacher Professionalism in Improving Learning Quality. Journal of Educational Management 24 (1): 9-20.

Tirto. 2019. Indonesia's Education Index is Low, Competitiveness is Weak. tirto.id. Accessed 12 October 2020. https://tirto.id/indeks-pend Pendidikan-indonesia-rendah-daya-saing-pun-lemah-dnvR.

Uno, Hamzah B. 2008. Learning Model. Jakarta: PT Bumi Aksara.

Viva. 2019. World Education Survey, Indonesia Ranks 72 out of 77 Countries. December 5, 2019. https:// www.viva.co.id/arsip/1249962-survei-pend Pendidikan-dunia-indonesia-per Rank-72-dari-77-negara. 